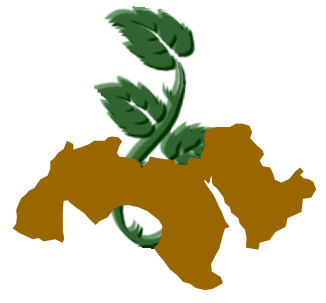

Arab Univ.

J. Agric. Sci., Ain Shams Univ., Cairo, 18(1), 171-177, 2010

\title{
PRODUCTION OF HEALTHY YOGHURT BY USING Aqueous Extract of Garlic
}

\author{
Fatma A.M. Hassan'; Wafaa. A. Helmy²; A.K. Anab'; \\ Hala M. Bayoumi ${ }^{1}$ and H. Amer ${ }^{2}$ \\ 1- Dairy Dep., National Research Center, Dokki, Cairo, Egypt \\ 2- Dep., of Natural and Microbial Products Chemistry, National Research Center, Dokki, Cairo, \\ Egypt
}

Keywords: Healthy yoghurt, Garlic extract, Garlic yoghurt

\section{ABSTRACT}

Garlic is promoted for use as a preventive factor against the formation of cancer. Although several compounds in garlic may have anti- cancer properties, the dially sulfide compounds are said to play a major role. garlic is known to help in regulating blood sugar levels. Therefore, yoghurt was manufactured by using the aqueous extract of garlic to produce a healthy yoghurt. Different concentration of this extract; $0.1,0.2,0.3,0.4$ and $0.5 \%$ were added to yoghurt milk. Results showed that $0.1 \%$ of garlic extract was the best concentration which gained the highest score. The resultant yoghurt treatments were analyzed chemically and organoleptically when fresh and after storage at $5+1^{\circ} \mathrm{C}$ until 15 days. Yoghurt acidity was gradually increased during storage at $5 \pm 1^{\circ} \mathrm{C}$ until 2 weeks, either for control or different treatments. On the other hand $\mathrm{pH}$ took an opposite trend of acidity. The resultant fresh yoghurt had high acetaldehyde, diacetyl, TVFA, viscosity values than control, whereas it showed low whey synersis. During storage at $\left(5 \pm 1^{\circ} \mathrm{C}\right)$ acetaldehyde, diacetyl decreased while TVFA, viscosity, whey synersis values were increased. Statistical analysis showed high significant difference $(\alpha 0.05)$ for acidity, TVFA, viscosity, diacetyl values and non significant difference ( $\alpha$ 0.05 ) for acetaldehyde content between treatments and during storage.

\section{INTRODUCTION}

Garlic (Allium sativaum L.,) a member of the Allium family (Liliaceae) contains a certain immune boosting properties that may help the body to fight off diseases, such as colds or the flu as well as reduce cancer cell growth. Garlic has been used traditionally for ages to treat a wide array of diseases, namely, respiratory infections, ulcers, diarrhea and skin infections (Fenwick and Hanley, 1985). According to data released at the first World Congress on the health, significance of garlic and garlic constituents, garlic extract reduced the incidence of breast cancer (in mice) by (70-90\%).

Yoghurt has a therapeutic properties and high nutritive value (He et al 2005). Yoghurt contains all the elements of nutrition found in milk in more digestible form. Lactic acid bacteria such as Streptococcus salivarius subs p.thermophilus which is used in manufacture of yoghurt having nutritional, dietetic and therapeutic properties (Kisla and Ünlüturk, 1998) control of intestinal infections, anticarcinogenic activity, improved lactose digestion in persons as classified as lactose maldigestors and control of serum cholesterol levels (Kisla and Ünlutürk, 1998 and Doombos, et al 2005).

Also lactic acid bacteria improve immune response and help the body to assimilate protein and lactose. Therefore, the aim of this work was production of healthy yoghurt by using garlic extract which help the people to fight off diseases. 


\section{MATERIALS AND METHODS}

\section{I- Materials}

\section{1- Fresh buffaloe's milk}

Fresh buffaloe raw milk was obtained from the faculty of Agric Cairo, Univ. The milk was skimmed using a mechanical separator the gross chemical composition of skim milk was: fat $1.0 \%$, Total solids $=10.88$, Total Protein 4.1, Lactose, $5.0 \%$ and ash 0.79 .

\section{2- Starter cultures}

Lactic starter cultures of thermophilic type (yoghunt yc-180) which consist of Streptococcus salivarius ss thermophilus and Lactobacillus delbrekii ss. bulgaricus were obtained from the agent of chr. Hansens laboratory Denmark A/S.

\section{3- Extraction of crude garlic aqueous extract}

The method of Whistler and Saarina (1957) was adapted with some modifications. The aqueous extract was extracted with hot Water. Ground garlic $(5 \mathrm{~g})$ was extracted, successively, with Water $(200 \mathrm{ml} \times 3)$ at $85^{\circ} \mathrm{C}$, under reflux, for $3 \mathrm{~h}(1 \times 3)$. After filtration, the combined extracts were treated with 3 vols of ethanol and the resulted isolated by centrifugation, dried and weighted.

\section{II - Methods}

\section{1- Preparation of yoghurt}

Skim milk buffaloe's was heated at $85^{\circ} \mathrm{C}$ for 15 min cooled to $45^{\circ} \mathrm{C}$ divided into five portions. The first portion was let as control without garlic, the other protions were fortified with different concentrate of garlic $0.1,0.2,0.3,0.4,0.5$ respectively. All treatments were inoculated with $2 \%$ yoghurt starter Streptococcus salivarius ss thermophilus and Lactobacillus delbrekii ss bulgaricus and incubated at $42^{\circ} \mathrm{C}$ for about three hours until complete coagulation and then stored at $5 \pm 1^{\circ} \mathrm{C}$. The resultant yoghurt was organoleptically evaluated by a panel of ten experts. The preferred treatment $(0.1)$ was analysed periodically for chemical and organoleptic properties up to 15 days of storage.

\section{2- Preliminary experiments}

Preliminary experiments were carried out to select the best ratio of garlic extract garlic extract was added by the ratios $0.1,0.2,0.3,0.4$ and $0.5 \%$ respectively. Sensory evaluation of the fresh yoghurt indicated that $0.1 \%$ was the best ratios which gained the best score value.

\section{3- Analysis of milk and yoghurt}

Total solids were determined according to IDF (1982). Titratable acidity, fat content were determined according the Ling (1963). Total protein content was assessed by Kjeldahel method (IDF, 1993). $\mathrm{pH}$ values were measured using a digital $\mathrm{pH}$ meter model HANNA at 4817, equipped with a combined glass electrode and lactose according to Nickerson et al (1976), total volatile fatty acids were determined as reported by Kosikowski (1982) while acetaldehyde and diacetyl content was determined according to Lees and Jago (1969). Viscosity of yoghurt was determined using zum viscosimeter type-RN-50Hz. Statistical analysis were performed using GLM procedure with SAS (2004).

Total carbohydrates were determined after complete acid hydrolysis according to (Dubois, 1956). The resulted acid hydrolysates were examined by $\mathrm{PC}$ using $\mathrm{n}-\mathrm{BuOH}-\mathrm{Me}_{2} \mathrm{CO}-\mathrm{H}_{2} \mathrm{O}$ (4:5:1) Jayme and Knolle (1956), and aniline phthalate as spraying reagents Partridge (1949). Quantitative determination of separated sugars was carried out according to Wilson method (1959). Total nitrogen of the investigated samples $(0.3 \mathrm{gm})$ was determined adopting the usual Micro-Kjeldahl's method (AOAC, 1970). The crude protein was calculated by multiplied the total nitrogen by 6.25 Black (1948).

\section{4- Total colony count of aqueous garlic extract}

The total colony count of bacteria was performed using the pour plate method using nutrient agar (oxoid) as follows:

One gram of garlic extract was serially diluted and $10 \mathrm{ml}$ of an appropriate dilution was used to inoculate the plate in duplicate. The plates were incubated at $37^{\circ} \mathrm{C}$ for $24 \mathrm{hrs}$, after which the total colony count was determined as previously described (Nwachukwu, 2000).

Similarly, the total count of the fungi, dilutions of the extract were surface-spread on potato dextrose agar in duplicate and then incubated at $30^{\circ} \mathrm{C}$ for 48-96h. At the end of incubation, the colonies were screened based on the descriptions by Buchanan and Gibbons (1974). 


\section{RESULTS AND DISCUSSION}

Table (1a) indicates the chemical of aqueous garlic extract. Chemical composition was: total carbohydrates $25.5 \%$, protein $2.5 \%$ and galactose, glucose were $3.9 \%$, $98.1 \%$ respectively, whereas there is no manose, arabose and xylose. The microbiological examination of aqueous extract of garlic (Table 1b) show that the total bacterial count was $7 \times 10^{4} \mathrm{cfu} / \mathrm{gm}$ and free from yeast and fungi.

Table (2) show preliminary experiments, to establish the best concentration of garlic extract. Data obtained show that $0.1 \%$ of galric extract gained the highest score (91 points) improved the body, texture and flavour followed by control (87 points) whereas $0.5 \%$ of garlic extract had gained the lowest score (69 points). Accordinglly $0.1 \%$ of garlic extract was the best concentration which choosen for further experiments.

Table (3) illustrates the chemical composition of prepared yoghurt by using $0.1 \%$ garlic extract either when fresh or during storage period at $5^{\circ} \pm 1$. Acidity increased through storage until 2 week both control and garlic treatment. This may be due to the fermentation of lactose (Tamime and Deeth 1980). On the other hand $\mathrm{pH}$ took an opposite trend of acidity. These results agreement those of Hassan et al (1999) and Abou Dawood et al (1993). The same table indicates that TS, protein and ash increased gradually during cold storage (5 $\pm 1^{\circ} \mathrm{C}$ ) for 2 weeks.

Table (4) indicates the effect of cold storage (5 $\left.\pm 1^{\circ} \mathrm{C}\right)$ on viscosity $(\mathrm{Cp} / \mathrm{s})$ and whey synerthesis of prepared yoghurt by using $0.1 \%$ garlic extract. It is clear that viscosity of garlic yoghurt was higher than viscosity of control either fresh or during storage period. Viscosity increased during cold storage until 2 weeks. This increase may be attributed to the increase of acidity and the interaction between garlic extract as stabilizers and milk proteins (Schmidt and Smith, 1992).

From the same table whey syneresis was increased in both control and garlic treatment during storage up to 2 weeks. Garlic yoghurt showed lower whey syneresis than control either fresh or during cold storage. The garlic extract improved the yoghurt wheying off. These results are in accordance with Abd El-Salam et al (1996) and Hassan et al (1999).

Table (5) illustrates the effect of cold storage $\left(5 \pm 1^{\circ} \mathrm{C}\right)$ on total volatile fatty acids \& acetaldehyde, diacetyl of yoghurt prepared by using $0.1 \%$ garlic extract. It is clear that total volatily fatty acids was higher in garlic treatment than control yoghurt either fresh or during storage for 2 weeks. These results are in agreement with Abou Dawood et al (1993).

From the same table acetaldehy / $(\mu \mathrm{m} / 100 \mathrm{gm})$ in garlic treatment was higher than control, then gradually decreased during cold storage $\left(5 \pm 1^{\circ} \mathrm{C}\right)$ until 2 weeks either control or garlic treatment. The diacetyl $(\mu \mathrm{m} / 100 \mathrm{gm})$ took the same trend as acetyldehyde. These results are in agreement with Abou Dawood et al (1993) and Hassan et al (2001).

The effect of storage period $\left(5 \pm 1^{\circ} \mathrm{C}\right)$ on the organoleptic properties of yoghurt manufactured using $0.1 \%$ of galic extract is shown in Table (6). The total score gradually decreased during storge for 2 weeks in both control and garlic treated yoghurt. The score for appearance, body \& texture and flavour gradually decreased. This may be due to the whey syneresis and increasing acidity. However yoghurt manufactured with garlic had gained higher scores than control when fresh or during storage $\left(5^{\circ} \pm 1^{\circ} \mathrm{C}\right)$ for 2 weeks.

Table 1a. Some chemical, analysis of aqueous extract of garlic

\begin{tabular}{|c|c|c|c|c|c|c|c|}
\hline & & \multicolumn{5}{|c|}{ Monosaccharides Composition } \\
Compound & $\begin{array}{c}\text { Carbohydrates } \\
\text { (\%) }\end{array}$ & $\begin{array}{c}\text { Protein } \\
(\%)\end{array}$ & \multicolumn{5}{|c|}{} \\
\cline { 4 - 8 } & & & Gal. & Gluc & Man & Arab & Xyl \\
\hline Extract & 25.5 & 2.5 & 3.9 & 98.1 & -- & -- & -- \\
\hline
\end{tabular}


Table $1 \mathrm{~b}$. Some microbiological analysis of aqueous extract of garlic

\begin{tabular}{|c|c|}
\hline Total count & $\mathbf{7 \times 1 0 ^ { 4 } \mathrm { cfu } / \mathrm { gm }}$ \\
\hline Yeast & Free \\
Fungi & Free \\
\hline
\end{tabular}

Table 2. Organoleptic properties of yoghurt prepared by using different concentrations of garlic extract

\begin{tabular}{|c|c|c|c|c|}
\hline $\begin{array}{c}\text { Garlic extract } \\
\%\end{array}$ & $\begin{array}{c}\text { Appearance } \\
\mathbf{( 1 0 )}\end{array}$ & $\begin{array}{c}\text { Body \& Texture } \\
\mathbf{( 6 0 )}\end{array}$ & $\begin{array}{c}\text { Flavour } \\
\mathbf{( 3 0 )}\end{array}$ & $\begin{array}{c}\text { Total } \\
\mathbf{( 1 0 0 )}\end{array}$ \\
\hline Control & 8 & 52 & 27 & 87 \\
0.1 & 9 & 54 & 28 & 91 \\
0.2 & 7 & 51 & 26 & 84 \\
0.3 & 7 & 52 & 27 & 86 \\
0.4 & 5 & 50 & 24 & 79 \\
0.5 & 4 & 45 & 20 & 69 \\
\hline
\end{tabular}

Table 3. Effect of storage $\left(5 \pm 1^{\circ} \mathrm{C}\right)$ on chemical composition of prepared yoghurt by using $0.1 \%$ garlic extract

\begin{tabular}{|l|c|c|c|c|c|c|}
\hline \multirow{2}{*}{} & \multicolumn{3}{|c|}{ Control } & \multicolumn{3}{c|}{ Garlic Treatment } \\
\cline { 2 - 7 } & Fresh & 1 week & 2 week & Fresh & 1 week & 2 week \\
\hline Acidity \% & 0.78 & 1.11 & 1.78 & 0.82 & 1.17 & 1.70 \\
$\mathrm{pH}$ & 4.6 & 4.3 & 4.0 & 4.4 & 4.2 & 4.0 \\
TS \% & 11.7 & 11.9 & 12.3 & 12.0 & 12.1 & 12.4 \\
Fat \% & 0.3 & 0.32 & 0.34 & 0.31 & 0.33 & 0.36 \\
Protein \% & 4.65 & 4.67 & 4.69 & 4.67 & 4.69 & 4.72 \\
Ash \% & 0.89 & 0.92 & 0.93 & 0.91 & 0.93 & 0.95 \\
\hline
\end{tabular}

Table 4. Effect of cold storage $\left(5 \pm 1^{\circ} \mathrm{C}\right)$ on viscosity (CP/S) and whey synerthesis of prepared yoghurt by using $0.1 \%$ garlic extract

\begin{tabular}{|c|c|c|c|c|}
\hline \multirow{2}{*}{ Storage } & \multicolumn{2}{|c|}{ Control } & \multicolumn{2}{c|}{ Garlic Treatment } \\
\cline { 2 - 5 } Period & Viscosity Cp/s & Whey synerthesis & Viscosity Cp/s & Whey synerthesis \\
\hline Fresh & 12400 & 5.5 & 13480 & 4.2 \\
1 week & 28300 & 6.3 & 30400 & 5.4 \\
2 week & 53870 & 7.2 & 65500 & 6.5 \\
\hline
\end{tabular}


Table 5. Effect of cold storage $\left(5 \pm 1^{\circ} \mathrm{C}\right)$ on total volatile fatty acid (TVFA) $(0.1 \mathrm{~N}-\mathrm{NaOH} / 100 \mathrm{~g})$ and acetaldehyde $(\mu \mathrm{m} / 100 \mathrm{gm})$, diacetyl $(\mu \mathrm{m} / 100 \mathrm{gm})$ of yoghurt prepared by using $0.1 \%$ garlic extract

\begin{tabular}{|c|c|c|c|c|c|c|}
\hline \multirow{2}{*}{$\begin{array}{c}\text { Storage } \\
\text { period (week) }\end{array}$} & \multicolumn{3}{|c|}{ Control } & \multicolumn{3}{c|}{ Garlic Treatment } \\
\cline { 2 - 7 } & TVFA & acetaldehyde & diacetyl & TVFA & acetaldehyde & diacetyl \\
\hline Fresh & 8.16 & 325 & 230 & 8.93 & 337 & 240 \\
1 week & 12.50 & 295 & 180 & 12.72 & 312 & 192 \\
2 week & 17.34 & 272 & 140 & 18.16 & 286 & 151 \\
\hline
\end{tabular}

Table 6. Effect of storage period $\left(5 \pm 1^{\circ} \mathrm{C}\right)$ on organoleptic properties of yoghurt prepared by using $(0.1 \%)$ of garlic extract

\begin{tabular}{|c|c|c|c|c|}
\hline & $\begin{array}{c}\text { Appearance } \\
\text { (10) }\end{array}$ & $\begin{array}{l}\text { Body \& Texture } \\
(60)\end{array}$ & $\begin{array}{l}\text { Flavour } \\
\text { (30) }\end{array}$ & $\begin{array}{l}\text { Total } \\
(\mathbf{1 0 0 )}\end{array}$ \\
\hline & & Fresh & & \\
\hline Control & 8 & 53 & 27 & 87 \\
\hline garlic treatment & 9 & 54 & 28 & 91 \\
\hline & & 1week & & \\
\hline Control & 6 & 50 & 24 & 80 \\
\hline garlic treatment & 7 & 52 & 26 & 85 \\
\hline & & 2 weeks & & \\
\hline Control & 5 & 45 & 21 & 71 \\
\hline garlic treatment & 6 & 50 & 23 & 79 \\
\hline
\end{tabular}

\section{CONCLUSION}

The best concentration of garlic extract was $0.1 \%$ that could be used in preparing healthy yoghurt with improved appearance, body \& texture and flavour.

\section{REFERENCES}

Abd El-Salam, M.H.A.; H.M. El-Etriby and N.M. Shahein (1996). Influence of some stabilizers on some chemical and physical properties of yoghurt. Egyptian J. Dairy Sci., 24: 25-32.

Abou Dawood, A.E.; F.H. Abd Rabo; N.S. Ahmed and F.A.M. Hassan (1993). Manufacture of yoghurt from goats milk. Egyptian. J. Dairy Sci., 21: 21-33.
AOAC (1970). Official Methods of Analysis. The Association of Official Agricultural Chemists. $11^{\text {th }}$ Ed. Washington, D.C.

Black, W.A.P. (1948). The Seasonal variation in chemical constitution of some of the sub-littoral seaweeds common to Scotland. J. Soc. Chem. Ind. London, 67: 165-168.

Buchanan, R.M. and N.E. Gibbons (1974). Bergey's Manual of Determinative Bacteriology. $8^{\text {th }}$ Ed. The Williams and Wilkins Company, Baltimore, U.S.A.

Doombos, A.M.; G.S. Meynen; H.C. Duchateau; Van der Knaap and E.A. Trautwein (2005). Intake occasion affects the serum cholesterol lowering of a plant sterol-enriched single dose yoghurt drink in mildly hypercholesterol emic subjects. Eur. J. Clin. Nutr., 60: 325-333. 
Dubois, M.K.; A. Gills; J.K. Hamilton; P.A. Rebers and F. Smith (1956). Colourimetric method for determination of sugars and related substances. Analytical Chemistry, 28: 350-356.

Fenwick, G.R. and B. Hanley (1985). The genus Allium Medicinal effects. CRC Crit. Rev. Food Sci. Nutr., 23: 1-73.

Hassan, Fatma A.M.; A.H. Wafaa and A.K. Enab (1999). Utilization of some local polysaccharide in manufacturing of yoghurt. Egyptian J. Dairy Sci., 27: 281-289.

Hassan, Fatma, A.M.; S.M. Samira and A.K. Enab (2001). Preparation of dairy products enriched with seasame seed protein. Egypt. J. Food Sci., 29: 79-93.

He, M.; Y.X. Yang; H. Han; J.H. Men; L.H. Bain and G.D. Wang (2005). Effects of yoghurt supplementation on the growth of preschool children in Bejing suburbs. Biomed. Environ. Sci., 18: 192197.

International Dairy Federation (IDF). (1982). Cheese and processed cheese determination of total solids content (Reference methods). International Dairy Federation Standard 4A., IDF. International Dairy Federation (IDF (1993). Milk determination of nitrogen content. International Dairy Federation Standard 2/B, IDF.

Jayme, G. and H. Knolle (1956). Paper chromatography of sugar mixtures upon glass fiber paper. Angew. Chem., 68: 243-246.

Kisla, D. and A. Ünlütürk (1998). A new type of fermented milk product manufacture by Lactobacillus acidophilus, Lactobacillus casei and Bifidobacterium longum. Adv. Food Sci., (CMTL) 20: 34-39.
Kosikowski, F.V. (1982). Cheese and Fermented Milk Food. $2^{\text {nd }}$ Ed. p. 225. Published and Distributed by Kosikowski, F.V. and Associates, P.O. Box 139 Brooktondale, New York .

Lees, G.J. and G.R. Jago (1969). Methods for the estimation of acetaldehyde in cultured dairy products. Australian J. Dairy Technol., 24: 181-188.

Ling, E.R. (1963). A Text Book of Dairy Chemistry. $3^{\text {rd }}$ Ed. Vol. 2: 140-144. Practical, Chapman and Hall, Ltd. London.

Nickerson, T.A.; I.F. Vujicic and A.Y. Lim (1976). Colourimetric estimation of lactose and its hydrolytic products. J. Dairy Sci., 59: 386-396.

Nwachukwu, S.C.U. (2000). Enhanced rehabilitation of tropical aquatic environment polluted with crude petroleum using Candida utilis. J. Environ. Biol., 21: 241-250.

Partridge, S.M. (1949). Aniline Hydrogen phthalate as spraying reagent for chromatography of sugars. Nature, 164: 443-446.

SAS (2004). Statistical Analysis System, SAS User's Guide. Institute Inc. Editors Cary, NC.

Schmidt, K.A. and D.E. Smith (1992). Rheolgoical properties of gum and milk protein interactions. J. of Dairy Science, 75(1): 36-39.

Tamime, A.Y. and H.C. Deeth (1980). Yoghurt: Technology and bio chemistry J. Food Protection. 43: 939-942.

Whistler, R.L. and J. Saarina (1957). Extraction of crude garlic aqueous extract. J. of the American Chemical Society, 79: 6055-6065.

Wilson, C.M. (1959). Quantitative Determination of Sugars on paper chromatograms. Analytic. Chem., 31: 1199-1201. 